\title{
Fusulinids from the Howe Limestone Member (Red Eagle Limestone, Council Grove Group) in Northeastern Kansas and their Significance to the North American Carboniferous (Pennsylvanian)-Permian Boundary
}

\author{
Gregory P. Wahlman ${ }^{1}$ and Ronald R. West ${ }^{2}$ \\ ${ }^{1}$ Wahlman Geological Services, 12303 Lanny Lane, Houston, Texas 77077 \\ ${ }^{2} 1014$ Houston Street, Manhattan, Kansas 66502
}

\begin{abstract}
Fusulinids from the Howe Limestone Member (upper part of the Red Eagle Limestone, lower part of the Council Grove Group) are described here for the first time. The Howe fauna is particularly significant because it represents the earliest fusulinids known to occur above the new conodontbased Carboniferous (Pennsylvanian)-Permian boundary at the Glenrock Limestone Member-Bennett Shale Member contact (Red Eagle Limestone) in northeastern Kansas. The Howe fusulinid assemblage is composed entirely of species of the genus Leptotriticites. The species L. hughesensis and L. glenensis were originally described from just beneath the new systemic boundary horizon in the Hughes Creek Shale Member and Glenrock Limestone Member, respectively. L. wetherensis is a species from the Stockwether Limestone Member of north-central Texas, which is thought to directly overlie the new systemic boundary in that region. L. gracilitatus is a species reported from below and above the boundary in west Texas and New Mexico. Therefore, the Howe Limestone Member fusulinid fauna is quite transitional in character. The first typical and diagnostic early Permian (Wolfcampian Series) fusulinids in the midcontinent section appear in steps through the stratigraphically higher Neva Limestone Member of the Grenola Limestone (Paraschwagerina kansasensis), and the Cottonwood and Morrill Limestone Members of the overlying Beattie Limestone (Schwagerina jewetti, S. vervillei). This offset of conodont and fusulinid faunal changes should be taken into account in regional and interregional biostratigraphic correlations of the new systemic boundary.
\end{abstract}

\section{Introduction}

The Howe Limestone Member of the Red Eagle Limestone (Council Grove Group) of Kansas is the first named limestone unit above the recently designated conodont-based Carboniferous (Pennsylvanian)-Permian boundary in the North American midcontinent (Sawin et al., 2006; figs. 1 and 2). No fusulinids have been previously described from the Howe Limestone
Member. Fusulinids are widely used index fossils for late Paleozoic marine strata, and so the Howe fusulinid fauna is significant for the definition and correlation of the new systemic boundary throughout North America. Fusulinid assemblages from two Howe Limestone Member localities in northeastern Kansas (fig. 1) are discussed in this study.

\section{Carboniferous (Pennsylvanian)-Permian Boundary}

The conodont-based Carboniferous (Pennsylvanian)Permian Global Stratotype Section and Point (GSSP) was designated in the southern Ural Mountains of Kazakhstan (Davydov et al., 1991) and was correlated with conodonts in midcontinent North America by Ritter (1995) and Chernykh and Ritter (1997). That conodont-based correlation shifted the traditional North American midcontinent systemic boundary from the base of the Admire Group upsection to the contact of the Glenrock Limestone and Bennett Shale Members of the Red Eagle Limestone in the lower part of the Council Grove Group (fig. 2).

During most of the 20th century, the Carboniferous (Pennsylvanian)-Permian boundary in the North American midcontinent was placed at a regional unconformity between the Wabaunsee and Admire Groups (Moore, 1940; fig. 2). As a result, fusulinids (e.g., Thompson, 1954) and other fossil assemblages from the Admire Group and overlying lower part of the Council
Grove Group, and correlative units throughout North America, were dated as earliest Permian (early Wolfcampian). Ross (1963, fig. 11), in a study of the fusulinids of the Wolfcampian stratotype in the Glass Mountains of west Texas, recognized that the North American boundary horizon did not correlate well biostratigraphically with the Eurasian Carboniferous-Permian boundary. Ross (1963, fig. 11) suggested that in North America the Carboniferous (Pennsylvanian)-Permian boundary could be placed slightly higher in the section at the base of the zone of inflated schwagerinids (Pseudoschwagerina, Paraschwagerina), which is at the base of the Neal Ranch Formation in the Wolfcampian stratotype. Ross and Ross (1987a,b) proposed two new Wolfcampian substages in the stratotype, the Nealian and Lenoxian, based on the Neal Ranch and overlying Lenox Hills Formations, both of which are unconformity-bound units. Davydov et al. $(1991,1992)$ proposed to the International Stratigraphic Subcommission that the base of the Permian

\footnotetext{
NOTE: Kansas Geological Survey (KGS) editorial policy concerning usage of stratigraphic nomenclature and issues related to that usage is based on guidelines set up by the KGS Stratigraphic Nomenclature Committee (www.kgs.ku.edu/General/Strat/index.html). In accordance with those guidelines, Series designations in the Permian as used in Kansas were published in KGS Bulletin 254, part 2, in 2008 (www.kgs.ku.edu/Current/2008/Sawin/index.html). The senior author herein considers the Wolfcampian to be a Stage; however, because of current KGS editorial policy, the Wolfcampian is referred to as a Series in this revision.
} 


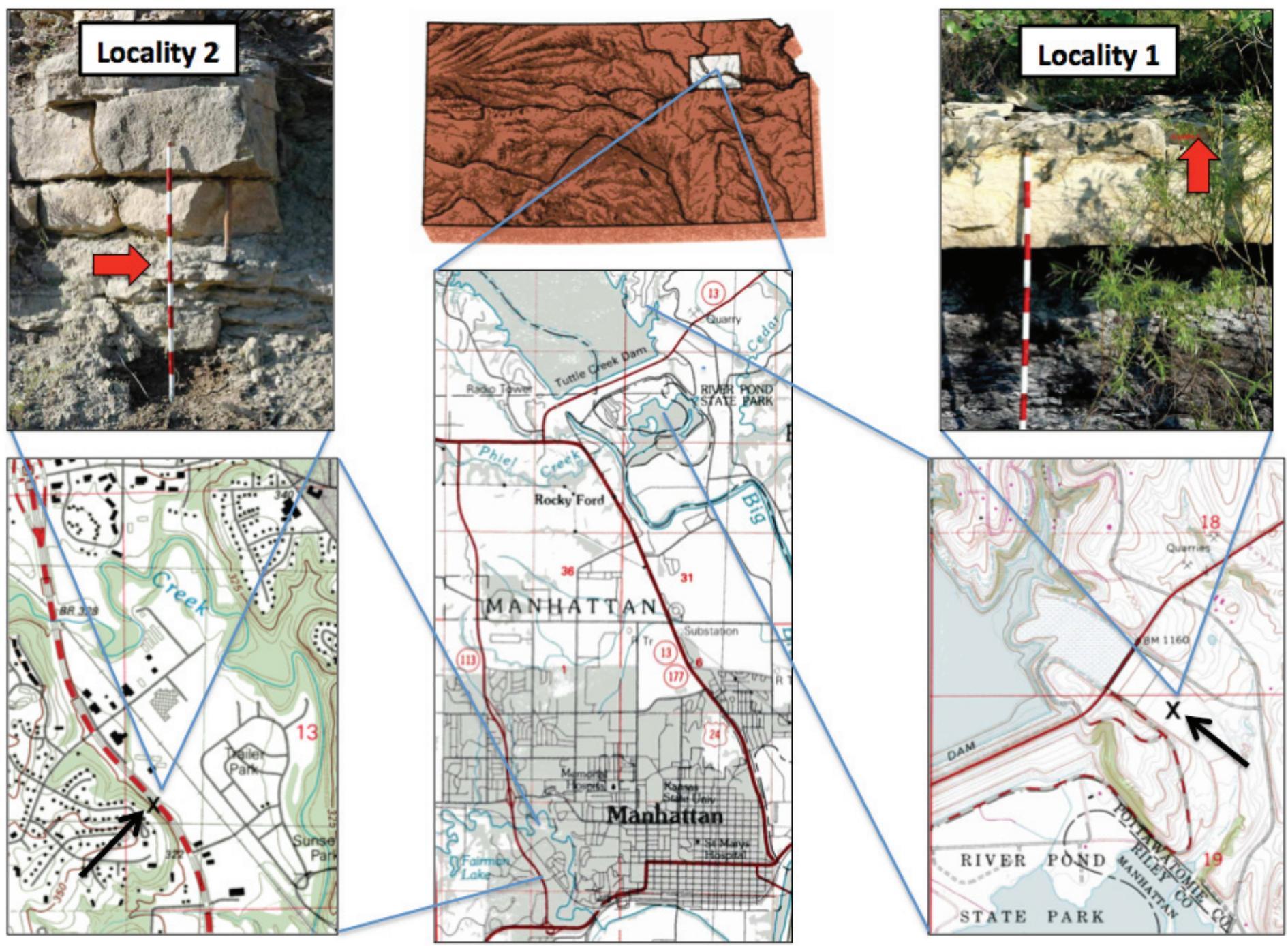

FIGURE 1-Maps and photographs of the two Howe Limestone Member fusulinid sample localities discussed herein. The solid red arrows in the outcrop photographs point to the horizons where the fusulinid samples were collected. North in all maps is toward the top of the page.

System in type-Eurasian region be designated at the base of the Asselian Stage in the southern Ural Mountains of Kazakhstan based on the appearance of the conodont Streptognathodus isolatus and on the slightly higher appearance of the first inflated schwagerinid fusulinids (Sphaeroschwagerina). Citing that proposal, Baars et al. (1994) proposed that the Carboniferous (Pennsylvanian)-Permian boundary in the North American midcontinent be elevated from the traditional WabaunseeAdmire Group boundary to the Neva Limestone Member of the Grenola Limestone (middle part of the Council Grove Group) in Kansas, where the first North American inflated schwagerinid Paraschwagerina kansasensis (Beede and Kniker) appears. Then, Ritter (1995) and Chernykh and Ritter (1997) correlated the conodont faunas from the proposed Uralian boundary stratotype with those of midcontinent North America to a slightly lower horizon at the contact of the Glenrock Limestone and Bennett Shale Members of the Red Eagle Limestone (lower part of the Council Grove Group; fig. 2). A few years later, the International Stratigraphic Subcommission approved the definition of the base of the Asselian Stage at the first occurrence

FIGURE 2 (following) - Fusulinid species range chart, lithostratigraphy, and cyclothemic depositional sequences for Admire, Council Grove, and lower part of the Chase Groups in Kansas. To the right of the lithostratigraphic column is a generalized sea-level curve, showing red beds (thick red lines) and coal beds (thick black lines). To the right of the sea-level curve, vertical red and blue lines represent individual 4th order sequences. Solid red arrows indicate 3rd order sequence boundaries, based on Boardman et al. (2009). HST means highstand systems tract, and TST means transgressive systems tract, and those system tracts are labeled only for the 3rd order cycles. The recently conodont-based midcontinent Carboniferous (Pennsylvanian)-Permian boundary at the Glenrock limestone-Bennett shale contact (Red Eagle Limestone, lower part of the Council Grove Group) is marked by a solid red line across the chart. Stratigraphic positions of global stage boundaries (Gzhelian, Asselian, Sakmarian, Artinskian) are based on conodont biostratigraphic correlations by Boardman et al. (2009). The Asselian/Sakmarian and Sakmarian/ Artinskian GSSP's have not been established internationally or in Kansas (International Commission on Stratigraphy, 2009; Sawin et al., 2008). 


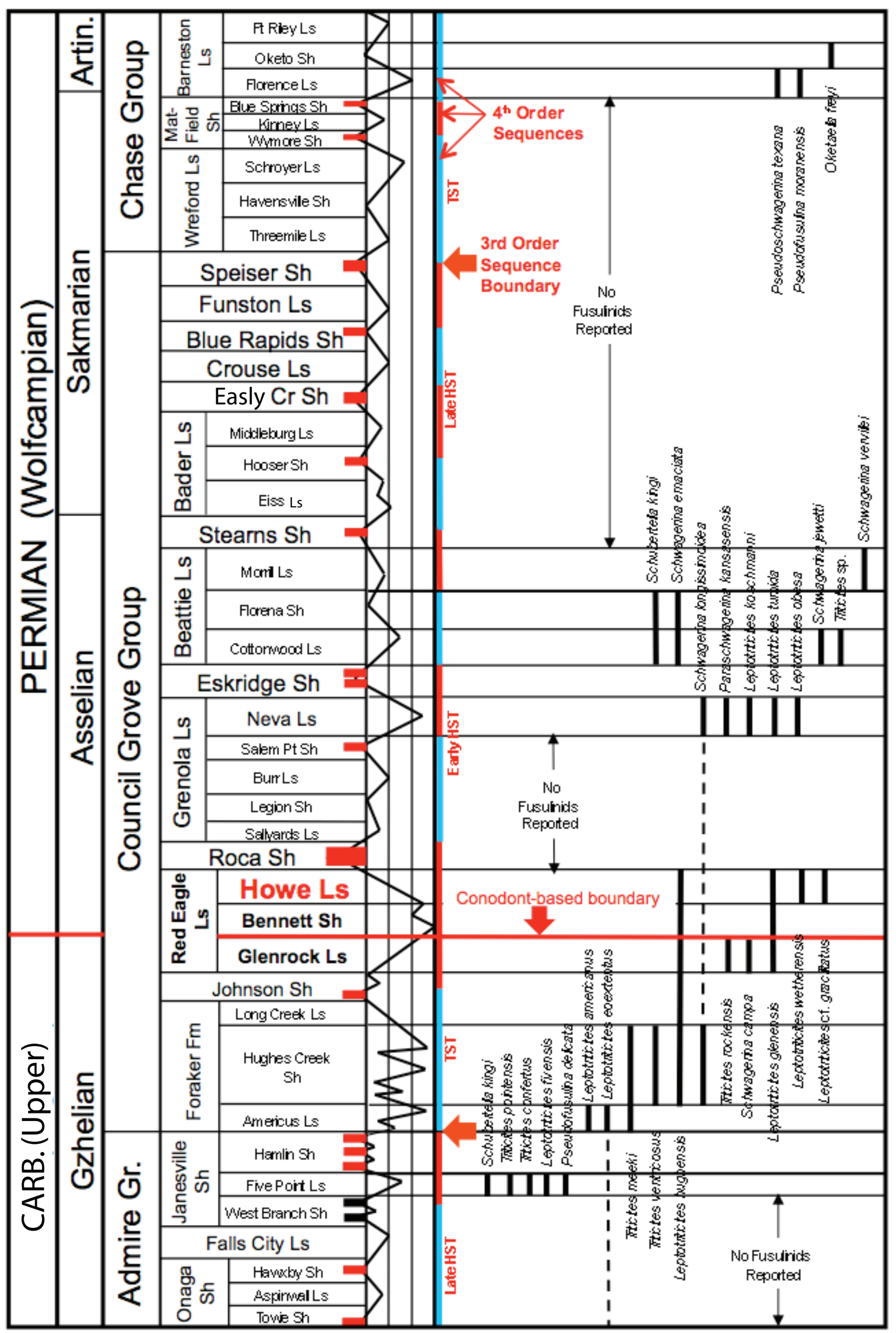


of Streptognathodus isolatus and the proposal of a new Global Carboniferous (Pennsylvanian)-Permian Boundary Stratotype Section (GSSP) in the southern Ural Mountains of Kazakhstan (Davydov et al., 1998). Boardman et al. (1998) recognized that horizon in Kansas at the Glenrock Limestone-Bennett Shale Members contact. Sawin et al. (2006) proposed the Red Eagle Limestone section at the Tuttle Creek Lake Spillway in Kansas (Locality 1 herein) as the North American boundary reference section. Wahlman (1998), Wahlman and King (2002), Wahlman and Kues (2004), and Wahlman (in prep.) have most recently discussed the fusulinid biostratigraphy of the new Carboniferous (Pennsylvanian)-Permian boundary interval in the midcontinent and southwestern United States, noting that further analyses of fusulinid faunas between the new boundary and the Neva Limestone Member of the Grenola Limestone in the midcontinent are needed.

\section{Previous Fusulinid Studies}

Thompson (1954) described the fusulinids of the Admire, Council Grove, and Chase Groups in Kansas when all three units were considered early Permian (Wolfcampian) in age. As described above, with the recent conodont-based correlation of the new global Carboniferous (Pennsylvanian)-Permian boundary from the Eurasian stratotype to the North American midcontinent, the Admire and lower part of the Council Grove Groups (below the Glenrock Limestone Member-Bennett Shale Member contact) are now considered to be latest Pennsylvanian (Virgilian, Gzhelian) (fig. 2). As shown by Thompson (1954), the Admire and lower part of the Council Grove fusulinids are characterized by large species of Triticites, several species of Leptotriticites (which Thompson called Dunbarinella), and the earliest primitive species of Schwagerina. Ross and Ross (1994, 1998) suggested the orphaned interval from the base of the Admire to the new systemic boundary be designated a new stage, the Bursumian. However, that proposal has not been widely accepted, and most authors have placed the orphaned interval into the uppermost Pennsylvanian Virgilian Stage. The arguments against the Bursumian concept are 1) the lack of definitive supporting conodont data for the lower boundary; 2) the finding that the fusulinid genus Leptotriticites, once considered a typical "Bursumian" genus, actually appears lower in the section, within the middle and upper parts of the Wabaunsee Group (Virgilian) of Kansas (Douglass, 1962; Sanderson and Verville, 2000; Sanderson et al., 2001); and 3) the facies of the Bursum Formation that crop out in New Mexico do not contain faunas sufficient to define a new chronostratigraphic unit.

Fusulinids in the Glenrock Limestone Member of the Red Eagle Limestone, which directly underlies the new Carboniferous (Pennsylvanian)-Permian boundary at its contact with the Bennett Shale Member, are Leptotriticites glenensis (Thompson, 1954), Schwagerina campa (Thompson, 1954), and Triticites rockensis (Thompson, 1954) (fig. 2). Leptotriticites glenensis is slightly larger than most earlier species of Leptotriticites from the Wabaunsee, Admire, and lower part of the Council Grove Groups (Thompson, 1954; Sanderson et al., 2001), and is slightly smaller than the stratigraphically higher species of the genus in the Neva Limestone Member (Grenola Limestone). Schwagerina campa is a relatively small, elongate, primitive species of that genus. Triticites rockensis is a rather small species relative to other Admire-Council Grove Triticites (e.g., T. ventricosus), and it has some morphological characteristics that are more similar to earlier Triticites in the late Virgilian Wabaunsee Group (Thompson, 1954).

O'Connor and Jewett (1952) illustrated a few fusulinids in photomicrographs of the Bennett Shale and Howe Limestone Members of the Red Eagle Limestone, but did not identify or describe the specimens.

Thompson (1954, fig. 2) did not describe any fusulinids in the interval between the Glenrock Limestone Member-Bennett Shale Member contact and the base of the Neva Limestone Member of the Grenola Limestone, where the first inflated schwagerinid Paraschwagerina kansasensis (Beede and Kniker) appears. The Neva fauna also contains Schwagerina longissimoidea (Beede, 1916), a large, elongate, and primitive species of the genus whose range straddles the new systemic boundary (fig. 2), and the stratigraphically highest and largest species of Leptotriticites, i.e., L. tumida (Skinner, 1931), L. obesa (Beede, 1916), and L. koschmanni (Skinner, 1931). Thompson's (1954, fig. 2) chart showed another thin interval lacking fusulinids above the Neva Limestone Member. The next higher fusulinid assemblage in the section is from the Cottonwood and Morrill Limestone Members of the Beattie Limestone, which contain typical early Wolfcampian morphotypes of Schwagerina (S. vervillei Thompson, 1954, and S.jewetti Thompson, 1954), and Schwagerina emaciata (Beede, 1916), which is also known from the Waldrip Shale Member of northcentral Texas and therefore straddles the new Carboniferous (Pennsylvanian)-Permian boundary. Thompson's (1954, fig. 2) chart then showed a thick stratigraphic interval (approximately $230 \mathrm{ft}$ ) above the Beattie Limestone that lacks fusulinids, and the first inflated Pseudoschwagerina (P. texana Dunbar and Skinner, 1937) appears in the Florence Limestone Member of the Barneston Limestone (Chase Group), which is late Wolfcampian. It is noteworthy that although the Wolfcampian is commonly referred to as the Zone of Pseudoschwagerina, that genus does not appear until high above the (Carboniferous) Pennsylvanian-Permian boundary in the midcontinent, probably because of unsuitable offshore normal marine environments through the upper part of the Council Grove and lower part of the Chase Groups (fig. 2).

\section{Howe Limestone Member Stratigraphy}

The Howe Limestone Member of the Red Eagle Limestone was named by Condra (1927, p. 86) for a 4-ft (1.22-m)-thick, gray, massive, and dense, poorly fossiliferous, vuggy limestone that weathers buff to yellowish and crops out south of Howe, Nebraska. Moore et al. (1951) described the Howe Limestone Member as consisting of variable facies and ranging from less 
than $1 \mathrm{ft}$ to $15 \mathrm{ft}(0.3-4.57 \mathrm{~m})$ in thickness. O'Connor and Jewett (1952) pointed out north-to-south lithologic changes in the Howe Limestone Member, being composed of vuggy dolomites in Nebraska and northern Kansas, to granular and fossiliferous limestones in central Kansas, and then to massive fine-grained limestone in southern Kansas and Oklahoma. Zeller (1968) described the Howe Limestone Member as a fine-grained algal limestone containing tiny pelecypods and gastropods, ostracodes, and foraminifers. McCrone (1963) described the Howe Limestone Member in southern Nebraska and northern Kansas as a characteristically fine-grained, massive, sparsely fossiliferous limestone that is deeply weathered and has a very vuggy nature. McCrone further described that the Howe Limestone Member changed southward through central and southern Kansas to pseudo-oolitic, pelletoid, and osagiid limestones, and that in southern Kansas and adjacent northern Oklahoma the upper part of the Howe Limestone Member was characterized by large stromatolitic and osagiid masses.

The Howe Limestone Member is the upper regressive highstand limestone of the Red Eagle Limestone cyclothem. Boardman and Nestell (2000) and Boardman et al. (2009) defined the Red Eagle cyclothem as a composite 4th order depositional sequence, composed of, in ascending order, the upper part of the Johnson Shale, the Red Eagle Limestone (Glenrock Limestone, Bennett Shale, and Howe Limestone Members), and the Roca Shale (fig. 2). Within the Red Eagle 4th order depositional sequence, those authors recognized six 5 th order sequences $(\mathrm{A}-\mathrm{F})$, with the bottom three $(\mathrm{A}-\mathrm{C})$ being subtidal cycles and the upper three (D-F) being more marginal-marine to nonmarine exposure cycles. The basal 5 th order sequence $\mathrm{A}$ is developed entirely within the upper part of the Johnson Shale. The 5th order sequence B is composed of the Glenrock Limestone and lower part of the Bennett Shale Members of the Red Eagle Limestone, with transgression throughout Glenrock deposition to a maximum flooding surface in the basal part of the Bennett shale. The 5 th order sequence $\mathrm{C}$ is entirely within the upper part of the Bennett shale. The 5th order sequence D is composed of the Howe Limestone Member and the paleosols of the overlying lower part of the Roca Shale. The 5th order sequences E and F are nonmarine to marginal-marine cycles in the middle and upper parts of the Roca Shale, respectively.

The Glenrock Limestone Member is the transgressive limestone of the Red Eagle 4th order cyclothemic depositional sequence (fig. 2). Transgression continued into the overlying Bennett Shale Member where two condensed maximum flooding horizons occur in the basal $0.3 \mathrm{~m}$ and contain the basal Permian conodont index fossil Streptognathodus isolatus, along with orbiculoid brachiopods, ammonoids, and fish debris (Boardman et al., 1995). The upper part of the Bennett Shale Member generally contains deeper-water to offshore shelf fossil biotas. The Howe Limestone Member is the highstand marine regressive facies of the Red Eagle 4th order cyclothemic depositional sequence and is overlain by the thick, mostly nonmarine, lower part of the Roca Shale, which is composed of stacked paleosols (Miller et al., 1996). The Howe Limestone Member represents widespread shallow-water, normal to restricted marine conditions. The northern mud-rich sparsely fossiliferous carbonate facies represent shallow subtidal, normal to restricted marine shelf paleoenvironments, and the more southern grainrich and algal-rich facies represent higher-energy, very shallow subtidal to peritidal, restricted marine paleoenvironments.

Significantly, according to Sawin et al. (2006), the condensed horizons in the lower part of the Bennett Shale Member represent the maximum flooding events for the entire Admire-Council Grove interval in the midcontinent. Those authors cited evidence that the amplitude of sea-level fluctuations and the sedimentary characteristics of cyclothem sequences changed after Red Eagle deposition. Geochemical evidence from paleosols through the stratigraphic section indicates that the more humid paleoclimatic conditions of the Late Pennsylvanian changed after Red Eagle deposition to distinctly more arid paleoclimatic conditions in the overlying section (Miller et al., 1996).

\section{Study Materials}

In 2007, Ron West (Kansas State University, Manhattan) and Robert Sawin (Kansas Geological Survey) collected two fusulinid-bearing samples from the Howe Limestone Member at the Tuttle Creek Lake Spillway section in northeast Kansas (Locality 1, fig. 1), which Sawin et al. (2006) proposed as the Carboniferous (Pennsylvanian)-Permian boundary reference section in Kansas. Those samples were sent to the senior author for analysis of the fusulinids. The samples were brownish-yellow skeletal limestone (wackestone and packstone) that were severely recrystallized and somewhat leached, with numerous large fusulinid skelmolds on the surface; however, after slabbing the samples it was found that they also contained some preserved fusulinids. The fusulinid skelmolds all have a similar size and fusiform shape to the preserved specimens, and none of the skelmolds appeared to represent inflated fusulinid shell forms. Fusulinids in the recrystallized, leached limestone are not very well-preserved, and the soft nature of the limestone made it rather difficult to thin-section the fusulinids without losing parts of the specimens. Nevertheless, 16 oriented fusulinid thin sections were made from the two samples (Plate 1). Associated fossils in the samples are bryozoan and brachiopod fragments, echinoderm ossicles, and smaller foraminifers (e.g., Globivalvulina, palaeotextulariids), an assemblage that represents a normal marine-shelf paleoenvironment.

In 2009, Ron West collected fusulinids from a second Howe Limestone Member locality (Locality 2, fig. 1), from an outcrop along South Seth Child Road (Hwy 113), about 1,400 ft (426.72 m) south-southeast of the intersection with Amherst Avenue in Manhattan, Kansas, which is located about $5.5 \mathrm{mi}(8.85 \mathrm{~km})$ south-southwest of the Locality 1 exposure at the Tuttle Creek Lake Spillway. The occurrence of the fusulinids in this sample corresponds with unit 34 of West (1994), occurring $1.3 \mathrm{ft}(40 \mathrm{~cm})$ above the base of the Howe Limestone Member. O'Connor and Jewett (1952) noted that the lithofacies of the Bennett shale are quite variable from north to south. The Bennett Shale MemberHowe Limestone Member contact is rather transitional in the Locality 2 area, and the sampled interval could be considered the lowermost part of the Howe Limestone Member or the uppermost 
part of the Bennett Shale Member (see O'Connor and Jewett, 1952; McCrone, 1963; Clark, 1989). The locality 2 sample comes from a relatively light-colored brownish-gray calcareous mudrock interval between the base of the massive Howe Limestone Member and the top of the dark (black) mudrocks/ shales of the Bennett Shale Member. The light-colored mudrock facies was assigned to the basal part of the Howe limestone in this study mainly because it contains a relatively shallow-water fossil assemblage that is characteristic of the Howe Limestone Member, including articulate brachiopods, bryozoans, and fusulinids. Fusulinids have not been reported from the Bennett Shale Member in the area. As noted by O'Connor and Jewett (1952, p. 340-341) and McCrone (1963), the fossil assemblage in the Bennett Shale Member is composed of mostly orbiculoid and lingulid brachiopods, conodonts, fish teeth, ostracods, and agglutinated foraminifers. That distinct difference in fossil assemblages allows differentiating the two units where the Bennett Shale Member becomes predominantly limestone, as in the southern part of Kansas. As the Bennett Shale Member and Howe Limestone Member are part of the same depositional cycle, from a biostratigraphic viewpoint, the lithostratigraphic assignment of the unit is not important. The sample from Locality 2 consists of free fusulinid specimens in washed residue from the mudrock unit (fig. 2). Those free specimens vary in size and preservation, but all have elongate fusiform tests, and no inflated (i.e., Wolfcampian-like) shell forms were present. Many specimens were too weathered for thin-sectioning, but nine specimens were oriented and thin-sectioned (Plate 2).

\section{Systematic Paleontology}

Leptotriticites glenensis (Thompson, 1954) Plate 1, figs. 1-7; Plate 2, fig. 1

Description: Specimens from our samples assigned to $L$. glenensis have a moderately large shell size and a relatively inflated fusiform shell shape, with distinct axial fillings, rather irregularly fluted septa, and massive chomata.

Occurrence: Fusulinids from our Howe Limestone Member samples that were assigned to L. glenensis were found in samples from both Localities 1 and 2. Leptotriticites glenensis was originally described by Thompson (1954) from the Glenrock Limestone Member of the Red Eagle Limestone. Wahlman and King (2002) reported L. aff. L. glenensis from the "Bursumian" interval in the Robledo Mountains of New Mexico. Recently Stevens and Stone (2007) also recognized L. glenensis in their latest Pennsylvanian Fusulinid Zone 2 in the Bird Spring Group of southeastern California.

\section{Leptotriticites wetherensis (Thompson, 1954) Plate 2, figs. 2-4}

Description: Specimens from the Howe Limestone Member samples assigned to $L$. wetherensis have a moderately large shell size, very light to no axial fillings, minor to no septal fluting in the central part of the test, and relatively small knob-like chomata.

Discussion: Most of the type specimens of this species illustrated by Thompson (1954, Pl. 23, figs. 5-14) from the Camp Creek Shale and Stockwether Limestone Members of the Pueblo Formation in north-central Texas had slightly inflated fusiform shell shapes, but he also illustrated a more elongate fusiform morphotype (Plate 23, fig. 10) that the Howe Limestone Member specimens more closely resemble.

Occurrence: Specimens assigned to this species from our Howe Limestone Member samples are from Locality 2. Leptotriticites wetherensis was described by Thompson (1954) from the Camp Creek Shale and Stockwether Limestone Members of the Pueblo Formation in north-central Texas. According to Darwin Boardman (March 2010, personal communication), conodont assemblages from the maximum flooding horizon in the lower part of the Stockwether Limestone Member suggest that it may be slightly younger than the Red
Eagle Limestone of Kansas, and that the systemic boundary is probably in the underlying Camp Creek Shale Member interval. Recently Stevens and Stone (2007) recognized L. wetherensis in their Fusulinid Zone 2 of the Bird Spring Group of southeastern California.

\section{Leptotriticites hughesensis (Thompson, 1954) Plate 1, figs. 8-15; Plate 2, figs. 5-9}

Description: Several specimens from the Howe Limestone Member were assigned to this species because of their moderate shell size, elongate fusiform shell shape, tiny proloculus, axial fillings in the inner volutions, distinct chomata, and moderately developed and irregular septal fluting.

Occurrence: L. hughesensis was the most common species recognized from our Howe Limestone Member samples from both Localities 1 and 2 . The specimens from Locality 1 are slightly smaller than those from Locality 2, which might be an ecophenotypic response to somewhat less hospitable paleoenvironmental conditions. This species was originally described by Thompson (1954) from the Hughes Creek Shale Member of the Foraker Limestone in Kansas, which underlies the Red Eagle Limestone. Wahlman and King (2002) reported L. hughesensis from the "Bursumian" interval in the Robledo Mountains of New Mexico. Recently Stevens and Stone (2007) recognized L. hughesensis in their Fusulinid Zones 2 and 3 of the Bird Spring Group of southeastern California, suggesting that the species ranges across the Carboniferous (Pennsylvanian)Permian boundary in that area.

\section{Leptotriticites gracilitatus Skinner and Wilde, 1965} Plate 2, fig. 10

Description: One specimen from our Howe Limestone Member collections was tentatively assigned to this species based on its slightly smaller shell size, elongate fusiform shell shape, straight axis of coiling, very thin delicate walls, moderate septal fluting, and distinct chomata.

Occurrence: The single specimen assigned to this species occurred in the Howe Limestone Member at Locality 2. The species was originally described from the Big Hatchet Mountains of southeastern New Mexico by Skinner and Wilde (1965). 
On Wilde's (2006, fig. 5) fusulinid range chart for the Big Hatchet Mountains, the occurrence of L. gracilitatus is shown to be earliest Permian (early part of Nealian Substage). That occurrence matches well the earliest Nealian occurrence of the single Howe Limestone Member specimen. Wahlman and King (2002) reported L. aff. L. gracilitatus from the "Bursumian" interval in the Robledo Mountains of New Mexico.

\section{Leptotriticites and the Howe Limestone Member Assemblage}

All the fusulinids from the two exposures of the Howe Limestone Member are medium-sized fusiform species of Leptotriticites (Plates 1 and 2), a genus originally defined as a subgenus of Triticites by Skinner and Wilde (1965) in their study of fusulinids from the Big Hatchet Mountains of southwestern New Mexico. That subgenus was later elevated to genus status by Loeblich and Tappan (1987). Skinner and Wilde (1965) distinguished Leptotriticites by its distinctly thin and poorly developed two-layered schwagerinid test wall, a small proloculus, intense septal fluting, a narrow tunnel, and often massive chomata. Within Leptotriticites, they included all 10 midcontinent species assigned to Dunbarinella by Thompson (1954). They also recognized L. victorioensis (Dunbar and Skinner, 1937), a species originally described from the Wolfcampian Hueco Group of west Texas, and they described the new species L. hatchetensis Skinner and Wilde, 1965, and L. gracilitatus Skinner and Wilde, 1965, from the early Wolfcampian (Nealian) of the Big Hatchet Mountains, New Mexico.

For many years, Leptotriticites was considered characteristic of the interval previously considered to be "early Wolfcampian" (= Admire and lower part of Council Grove Groups = "Bursumian"), but with the upward shift of the Carboniferous (Pennsylvanian)-Permian boundary, that interval is now assigned to the latest Pennsylvanian (latest Virgilian or Gzhelian). As more fusulinid data were generated, Leptotriticites is now known to range from the late Virgilian (Wabaunsee Group of Kansas) to the late Wolfcampian (Lenoxian Substage of New Mexico and California) (fig. 3). Nevertheless, in the midcontinent and adjacent Permian basin region, Leptotriticites is most common in latest Virgilian to earliest Wolfcampian strata.

Wahlman and King (2002) cited Leptotriticites aff. L. glenensis, L. hughesensis, and L. aff. L. gracilitatus from the latest Pennsylvanian ("Bursumian") in the Robledo Mountains of south-central New Mexico.

Wilde (2006), in an expanded study of Big Hatchet Mountains fusulinids, described several new species of Leptotriticites, as well as the midcontinent species L. americana and L. fivensis from the so-called "Newellian" part of the section. "Newellian" is an unsubstantiated local term that he used for strata that are more or less equivalent to the "Bursumian" interval of Ross and Ross (1998), the PW-1 zone of Wilde (1990), and the Admire and lower part of the Council Grove Groups of the midcontinent. In the overlying Wolfcampian part of the Big Hatchet Mountains, in association with the inflated fusulinids Pseudoschwagerina and Paraschwagerina, Wilde also recognized L. hatchetensis, L. gracilitatus, and L. victorioensis, and described the new species L. aculeatus, L. globuloparvus, L. varius, L. pseudokoschmanni, L. cylindricus, and L. minoris. Some of those species ranged high into the late Wolfcampian (Lenoxian) section, extending the range of the genus much higher than is known in the midcontinent region.
Stevens and Stone (2007) recently recognized several species of Leptotriticites from the Bird Spring Group of southeastern California. From the latest Pennsylvanian Fusulinid Zone 2, they recognized $L$. aff. L. americanus, L. glenensis, $L$. aff. L. hatchetensis, L. cf. L. hughesensis, L. cf. L. varius, $L$. wetherensis, and L. cf. L. koschmanni. In their early Wolfcampian (Nealian) Fusulinid Zone 3, where Pseudoschwagerina and Paraschwagerina appear, they recognized $L$. aff. $L$. gracilitatus, L. aff. L. hatchetensis, L. cf. L. hughesensis, L. cf. L. koschmanni, and described the new species L. californicus and L. panamintensis. In their late Wolfcampian (Lenoxian) Fusulinid Zone 4, they described L. californicus n. sp. and $L$. warmspringensis n. sp., confirming Wilde's (2006) extension of the range of the genus into the late Wolfcampian (Lenoxian) in the southwestern United States.

The midcontinent species of Leptotriticites, which were described by Thompson (1954) as Dunbarinella, are, in ascending stratigraphic order: L. eoextenta (Waldrip Shale Member of Texas, and Americus Limestone Member of Kansas), L. extenta (Waldrip Shale Member of Texas), L. fivenesis (Five Point Limestone Member), L. americana (Americus Limestone Member), L. hughesensis (Hughes Creek Shale Member), L. glenensis (Glenrock Limestone Member), L. wetherensis (Camp Creek Shale and Stockwether Limestone Members of the Pueblo Formation, Texas), and the three large species $L$. koschmanni (Skinner, 1931), L. tumida (Skinner, 1931), and L. obesa (Beede, 1916) from the Neva Limestone Member of the Grenola Limestone (middle part of Council Grove Group). Those last three Neva Limestone Member species are the largest and stratigraphically highest species of the genus in the midcontinent and are the only previously described midcontinent species of Leptotriticites from above the new Carboniferous (Pennsylvanian)-Permian boundary horizon.

It is noteworthy that in studies on the fusulinids of Wolfcampian stratotype and underlying Late Pennsylvanian Gaptank Formation in the Glass Mountains of west Texas (Bostwick, 1962; Ross, 1963, 1965), the only Leptotriticites reported was L. koschmanni from the lower part of the Neal Ranch Formation (early Wolfcampian, Nealian), which suggests correlation to the Neva Limestone Member in the midcontinent.

Significantly, additional midcontinent species of Leptotriticites have been described and/or illustrated (but not formally described) from the late Virgilian Wabaunsee Group, which underlies the Admire Group. Douglass (1962) described $L$. brownvillensis (Douglass, 1962) from the Brownville Member of the Wood Siding Formation of Kansas, which is the uppermost unit of the Wabaunsee Group, and immediately underlies the Admire Group and the previously recognized systemic boundary. More recently, Sanderson and Verville (2000) illustrated, but did not formally describe and name, three species of Leptotriticites (L. "taylori," L. "elkensis," and L. n. sp.) from four horizons in 
the middle and upper parts of the Wabaunsee Group (below the Brownville limestone) in southeastern Kansas. Sanderson et al. (2001) showed the stratigraphic occurrences of those Waubaunsee species on a range chart of Virgilian fusulinids in Kansas.

The Leptotriticites from the midcontinent Howe Limestone Member belong to the closely related group of medium-sized species that includes L. americana, L. hughesensis, L. glenensis, and L. wetherensis. Thompson (1954) observed that this group of species was a series of closely related Leptotriticites that became progressively larger upward through the Admire and lower part of the Council Grove Groups. L. americana (Americus Limestone Member) is the smallest species in the series and is characterized by an elongate fusiform test with a straight axis and sharp poles, and relatively small chomata and slight axial fillings. L. hughesensis (Hughes Creek Shale Member) has a slightly larger test size, larger chomata, and more axial fillings. L. glenensis (Glenrock Limestone Member) is larger and more inflated than L. hughesensis, and has more massive chomata. $L$. wetherensis, from correlative strata in north-central Texas, has a fusiform to slightly inflated fusiform test shape, small chomata, and essentially no axial fillings. The species L. americana is probably ancestral to $L$. wetherensis as both are characterized by small chomata and little to no axial fillings. L. hughesensis was probably ancestral to L. glenensis, as both of those species are characterized by larger chomata and distinct axial fillings.

The Howe Limestone Member Leptotriticites assemblage described here includes L. hughesensis, L. wetherensis, $L$. glenensis, and L. aff. L. gracilitatus (fig. 1, Plates 1 and 2). The species L. hughesensis and L. glenensis were previously known from the lower part of the Council Grove Group just beneath the recently designated Carboniferous (Pennsylvanian)-Permian boundary. Leptotriticites hughesensis was described from the Hughes Creek Shale Member in the Foraker Limestone, where it was associated with large Triticites, such as T. ventricosus and

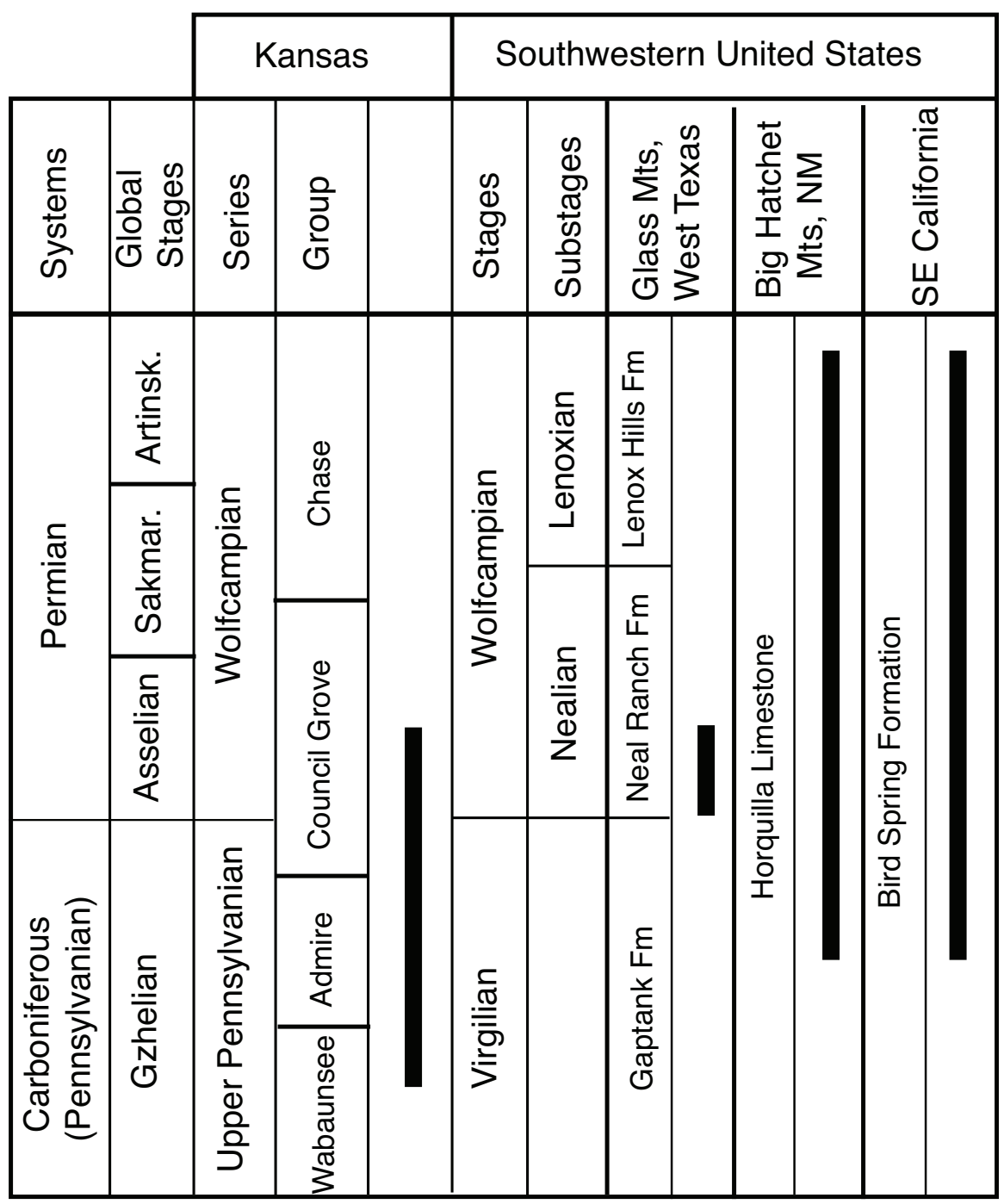

FIGURE 3-Ranges of the fusulinid genus Leptotriticites from important stratigraphic sections in the United States midcontinent (Kansas), Southwest (Glass Mountains, west Texas, and Big Hatchet Mountains, southwestern New Mexico), and Far West (Bird Spring Platform, southeastern California). Until recently, the range of Leptotriticites was generally considered to be only from the latest Virgilian ("Bursumian") to earliest Wolfcampian (early Nealian), as shown by Thompson (1954) (i.e., Admire to middle Council Grove Groups) in the northern United States midcontinent. However, Sanderson and Verville (2000) and Sanderson et al. (2001) reported older species of Leptotriticites from the Wabaunsee Group (late Virgilian) of Kansas, and Wilde (2006) and Stevens and Stone (2007) described species of Leptotriticites ranging up into the late Wolfcampian (Lenoxian) of New Mexico and California, respectively. 
T. meeki, and Schwagerina longissimoidea. L. glenensis was described from the Glenrock Limestone Member, immediately beneath the new systemic boundary, where it is associated with Schwagerina campa and Triticites rockensis. L. wetherensis was described by Thompson (1954) from the Camp Creek Shale and Stockwether Limestone Members of the Pueblo Formation in north-central Texas, where it is associated with Triticites ventricosus and T.creekensis, and Schwagerina campensis. According to Darwin Boardman (March 2010, personal communication), conodonts from the Stockwether Limestone Member suggest that it is slightly younger than the Red Eagle Limestone of Kansas, and that the systemic boundary is probably within the underlying Camp Creek Shale Member. Leptotriticites gracilitatus is a species described from the earliest Wolfcampian (Nealian) of New Mexico (Skinner and Wilde, 1965; Wilde, 2006), but $L$. aff. gracilitatus was also tentatively recognized in latest Pennsylvanian strata ("Bursumian") in the Robledo Mountains of New Mexico (Wahlman and King, 2002).

\section{Fusulinid Assemblages across the Midcontinent Carboniferous (Pennsylvanian)-Permian Boundary}

Fusulinid faunas appear to be quite transitional across the recently designated conodont-based Carboniferous (Pennsylvanian)-Permian boundary in the North American midcontinent (fig. 2). The Howe Limestone Member samples contain species of Leptotriticites that range upward from the lower part of the Council Grove Group (L.hughesensis and L. glenensis) beneath the systemic boundary, and earliest Wolfcampian (early Nealian) species (L. wetherensis and L. aff. L. gracilitatus) described from north-central Texas and New Mexico, respectively. The extension of the species ranges of L. glenensis and L. hughesensis across the systemic boundary is not surprising considering that the Glenrock and Howe Limestone Members are the transgressive and regressive phases, respectively, of the same Red Eagle 4th order depositional sequence, and the correlation of the early Nealian species matches the Howe Limestone Member position very well.

As previously noted, the maximum flooding horizon for the Admire-Council Grove-Chase Group interval is in the basal Bennett shale, where the basal Permian conodont assemblage occurs (fig. 2). According to geochemical studies on paleosols through that stratigraphic interval, a regional paleoenvironmental change occurred during the deposition of the Roca Shale, which overlies the Howe Limestone Member. Geochemical composition data from the Roca Shale stacked paleosols indicate the onset of more arid paleoclimatic conditions (Miller et al., 1996; Sawin et al., 2006). The overlying lower Grenola 4th order depositional sequence is composed of very shallow-water, marginal-marine facies that lack fusulinids. Then, in the next higher upper Grenola 4th order depositional sequence, the first definitive Wolfcampian inflated schwagerinid Paraschwagerina kansasensis appears in the Neva Limestone Member (fig. 2). Paraschwagerina kansasensis is associated with Leptotriticites koschmanni, L. tumida, and L. obesa, the largest and the stratigraphically highest species of that genus in the midcontinent, and with Schwagerina longissimoidea, a primitive species that ranges up from the Hughes Creek Shale Member across the new systemic boundary. Therefore, whereas the Neva Limestone Member assemblage contains the first early Permian inflated schwagerinid, it also contains several taxa that show a greater affinity to earlier faunas.

The next higher Beattie Limestone 4th order depositional sequence consists of two 5th order sequences (Boardman et al., 2009). The lower Beattie 5th order sequence is composed of the Cottonwood Limestone and Florena Shale Members, and their fusulinid assemblage consists of the lowest occurrence of
Schwagerina jewetti, the first more typical Wolfcampian species of that genus, S. emaciata, a species that ranges across the new systemic boundary, and the highest reported occurrence of the genus Triticites in the midcontinent (Thompson, 1954) (fig. 2). In the overlying upper Beattie 5th order depositional sequence, Schwagerina vervillei appears, which is morphologically similar to species of Schwagerina that co-occur with early species of Pseudoschwagerina in the early Nealian of the American Southwest (e.g., S. andresensis and S.pugunculus) (fig. 2).

In the midcontinent, the first Pseudoschwagerina (i.e., $P$. texana) does not appear until stratigraphically much higher, in the Florence Limestone Member of the Barneston Limestone (middle part of Chase Group) (fig. 2). In the American Southwest, Pseudoschwagerina texana is a large species that is preceded stratigraphically by several smaller and more primitive species (e.g., P. beedei, P. morsei). In fact, according to conodont data cited by Boardman et al. (2009, fig. 3), the Florence Limestone is the basal unit of the global Artinskian Stage, and therefore the entire Asselian-Sakmarian interval in midcontinent North America lacks Pseudoschwagerina. That delayed appearance of Pseudoschwagerina in the midcontinent is almost certainly due to the lack of suitable offshore paleoenvironmental conditions during the period of relatively low sea-level highstands represented by the upper part of the Council Grove and lower part of the Chase Groups.

It is noteworthy that the early Wolfcampian fusulinid assemblage of the middle part of the Council Grove Group in the northern midcontinent (i.e., Paraschwagerina kansasensis, Schwagerina jewetti, S.vervillei, S. emaciata, Leptotriticites koschmanni, L. tumida, and L. obesa) is apparently not present in the southern midcontinent outcrop section of north-central Texas. In Texas, there are about $100 \mathrm{ft}(30.5 \mathrm{~m})$ of strata that lack fusulinids between occurrences of $L$. wetherensis in the Camp Creek Shale and Stockwether Limestone Members of the Pueblo Formation, and Pseudoschwagerina texana and Schwagerina complexa in the Gouldbusk Limestone Member of the Moran Formation (Thompson, 1954, fig. 3). The thinner stratigraphic section and the lack of fusulinids in north-central Texas suggest that deposition of the earliest Wolfcampian (Nealian) was either nonmarine and abbreviated, or perhaps the Nealian marine section was removed by erosion during the so-called mid-Wolfcampian sea-level lowstand, a widespread erosional event that is strongly expressed in the adjacent Permian basin of west Texas. This question warrants further investigation. 


\section{Conclusion}

At the present state of knowledge, the change of fusulinid faunas across the recently designated conodont-based Carboniferous (Pennsylvanian)-Permian boundary in midcontinent North America is transitional in character. The appearance of the conodont Streptognathodus isolatus in the basal Bennett Shale Member of Kansas marks the new systemic boundary at a maximum flooding surface, but the fusulinid assemblages below and directly above the new conodont-based boundary are essentially the same. The first definitive early Permian (Wolfcampian Series) fusulinid (Paraschwagerina kansasensis) does not appear until the Neva Limestone Member of the Grenola Limestone, which is the regressive highstand limestone of the second 4th order depositional sequence above the new systemic boundary. In slightly higher Cottonwood and Morrill Limestone Members of the Beattie Limestone, additional typical early Wolfcampian fusulinids ap- pear (i.e., Schwagerina jewetti, S. vervillei). The gradual nature of the fusulinid assemblage turnover across the systemic boundary relative to that of the pelagic conodonts is probably related to the shallow-water benthic habitat of the fusulinids. Whereas the pelagic conodont assemblages appear to change relatively rapidly during the maximum flooding, changes in the benthic fusulinid assemblages might have been tied more closely to regional paleoenvironmental factors, such as the midcontinent paleoclimatic transition from humid to more arid conditions. The composition of fusulinid assemblages across the Carboniferous (Pennsylvanian)-Permian boundary changed gradually through several 4th order depositional sequences.

ACKNOWLEDGMENTS - We would like to thank Robert Sawin, Charles Ross, Calvin Stevens, and Merlynd Nestell for their manuscript reviews and their insightful comments and suggestions.

\section{References}

Baars, D. L., Ross, C. A., Ritter, S. M., and Maples, C. G., 1994, Proposed repositioning of the Pennsylvanian-Permian boundary in Kansas: Kansas Geological Survey, Bulletin 230, p. 5-9.

Beede, J. W., 1916, New species of fossils from the Pennsylvanian and Permian rocks of Kansas and Oklahoma: Indiana University Studies, v. 3, study 29 , p. 5-15.

Beede, J. W., and Kniker, H. T., 1924, Species of the genus Schwagerina and their stratigraphic significance: Texas University Bulletin 2433, p. 5-101.

Boardman, D. R., and Nestell, M. K., 2000, Outcrop-based sequence stratigraphy of the Council Grove Group of the midcontinent; in, Platform Carbonates of the Southern Midcontinent, K. S. Johnson, ed.: Oklahoma Geological Survey, Circular 101, p. 275-306.

Boardman, D. R., Wardlaw, B. R., and Nestell, M. K., 2009, Stratigraphy and conodont biostratigraphy of the uppermost Carboniferous and Lower Permian from the North American midcontinent: Kansas Geological Survey, Bulletin 255, part A, 41 p.

Boardman, D. R., Nestell, M. K., and Knox, L. W., 1995, Depth-related microfaunal biofacies model for Late Pennsylvanian and Early Permian cyclothemic sedimentary sequences in midcontinent North America; in, Sequence Stratigraphy of the Midcontinent, N. J. Hyne, ed.: Tulsa Geological Society, Special Publication No. 4, p. 93-118.

Boardman, D. R., Nestell, M. K., and Wardlaw, B. R., 1998, Uppermost Carboniferous and lowermost Permian deposition and conodont biostratigraphy of Kansas, USA; in, Permian Stratigraphy, Environments, and Resources, Volume 2, Stratigraphy and Environment, Jin Yugan, B. R. Wardlaw, and Wang Yu, eds.: Palaeoworld, v. 9, p. 19-32.

Bostwick, D. A., 1962, Fusulinid stratigraphy of beds near the GaptankWolfcamp boundary, Glass Mountains, Texas: Journal of Paleontology, v. 36, p. 1,189-1,200.

Chernykh, V. V., and Ritter, S. M., 1997, Streptognathus (Conodonta) at the Carboniferous-Permian boundary stratotype section, Aidaralash Creek, northern Kazakhstan: Journal of Paleontology, v. 71, p. 459-474.

Clark, M. H., 1989, Hierarchal genetic stratigraphy of the Red Eagle Limestone and Roca Shale formation (lower Permian) in northeast Kansas: M.S. thesis, Department of Geology, Kansas State University, Manhattan, 207 p.
Condra, G. E., 1927, The stratigraphy of the Pennsylvanian System in Nebraska: Nebraska Geological Survey, Bulletin 1, series 2, p. $1-291$.

Davydov, V. I., Barskov, I. S., Bogoslovskaya, M. F., Leven, E. Ya., Popov, A. V., Akhmetshina, L. Z., and Kozitskaya, R. I., 1991, The Carboniferous-Permian boundary in the USSR and its correlation (abs.): International Congress on the Permian System of the World, Perm, USSR, Program and Abstracts, p. A3.

Davydov, V. I., Barskov, I. S., Bogoslovskaya, M. F., Leven, E. Ya., Popov, A. V., Akhmetshina, L. Z., and Kozitskaya, R. I., 1992, The Carboniferous-Permian boundary in the former USSR and its correlation: International Geology Review, v. 34, no. 9, p. 889-906.

Davydov, V. I., Glenister, B. F., Spinosa, C., Ritter, S. M., Chernykh, V. V., Wardlaw, B. R., and Snyder, W. S., 1998, Proposal of Aidaralash as global stratotype section and point base for the Permian System: Episodes, v. 21, no. 1, p. 11-18.

Douglass, R. C., 1962, Fusulinidae of the Brownville through Americus interval in Kansas, p. 55-64; in, Stratigraphy and Paleontology of the Uppermost Pennsylvanian and Lowermost Permian Rocks in Kansas, M. R. Mudge and E. L. Yochelson, eds.: U.S. Geological Survey, Professional Paper 323, 213 p.

Dunbar, C. O., and Skinner, J. W., 1937, Permian Fusulinidae of Texas, v. 3, pt. 2, of the Geology of Texas: Texas University Bulletin 3701, p. 517-825.

International Commission on Stratigraphy, 2009, International Stratigraphic Chart: International Commission on Stratigraphy, one sheet, online at www.stratigraphy.org/column.php?id=Chart/ Time\%20Scale.

Loeblich, A. R., Jr., and Tappan, H., 1987, Foraminiferal genera and their classification: Van Nostrand Reinhold Co., New York, 2 vols., 970 p. and $270 \mathrm{p}$.

McCrone, A. W., 1963, Paleoecology and biostratigraphy of the Red Eagle Cyclothem (Lower Permian) in Kansas: State Geological Survey of Kansas, Bulletin 164, 114 p.

Miller, K. B., McCahon, T. J., and West, R. R., 1996, Lower Permian (Wolfcampian) paleosol-bearing cycles of the U.S. midcontinentEvidence of climatic cyclicity: Journal of Sedimentary Research, v. 66, p. 71-84.

Moore, R. C., 1940, Carboniferous-Permian boundary: American Association of Petroleum Geologists, Bulletin, v. 24, no. 2, p. 282-336. 
Moore, R. C., Frye, J. F., Jewett, W. L., and O'Connor, H. G., 1951, The Kansas rock column: Kansas Geological Survey, Bulletin 89, 132 p.

O'Connor, H. G., and Jewett, J. M., 1952, The Red Eagle Formation in Kansas: Kansas Geological Survey, Bulletin 96, part 8, p. 329-362.

Ritter, S. M., 1995, Upper Missourian-lower Wolfcampian (upper Kasimovian-lower Asselian) conodont biostratigraphy of the midcontinent, USA: Journal of Paleontology, v. 69, p. 1,139-1,154.

Ross, C. A., 1963, Standard Wolfcampian Series (Permian), Glass Mountains, Texas: Geological Society of America, Memoir 88, 205 p.

Ross, C. A., 1965, Late Pennsylvanian Fusulinidae from the Gaptank Formation, west Texas: Journal of Paleontology, v. 39, p. 1,1511,176 .

Ross, C. A., and Ross, J. R. P., 1987a, Late Paleozoic sea levels and depositional sequences; in, Timing and Depositional History of Eustatic Sequences-Constraints on Seismic Stratigraphy, C. A. Ross and D. Haman, eds.: Cushman Foundation for Foraminiferal Research, Special Publication No. 24, p. 137-149.

Ross, C. A., and Ross, J. R. P., 1987b, Biostratigraphic zonation of late Paleozoic depositional sequences; in, Timing and Depositional History of Eustatic Sequences - Constraints on Seismic Stratigraphy, C. A. Ross and D. Haman, eds.: Cushman Foundation for Foraminiferal Research, Special Publication No. 24, p. 151-168.

Ross, C. A., and Ross, J. R. P., 1994, The need for a Bursumian stage, uppermost Carboniferous, North America: Permophiles, No. 24, p. 3-6.

Ross, C. A., and Ross, J. R. P., 1998, Bursumian Stage, uppermost Carboniferous of midcontinent and southwestern North America: Carboniferous Newsletter, v. 16, p. 40-42.

Sanderson, G. A., and Verville, G. L., 2000, Upper Pennsylvanian (Virgilian) fusulinids from Elk and Chautauqua counties, Kansas: Kansas Geological Survey, Open-file Report 2000-12.

Sanderson, G. A., Verville, G. L., Groves, J. R., and Wahlman, G. P., 2001, Fusulinacean biostratigraphy of the Virgilian Stage (Upper Pennsylvanian) in Kansas: Journal of Paleontology, v. 75, p. 883-887.

Sawin, R. S., Franseen, E. K., West, R. R., Ludvigson, G. A., and Watney, W. L., 2008, Clarification and changes in Permian stratigraphic nomenclature in Kansas; in, Current Research in Earth Sciences: Kansas Geological Survey, Bulletin 254, part 2, online at www.kgs. ku.edu/Current/2008/Sawin/index.html.

Sawin, R. S., West, R. R., Franseen, E. K., Watney, W. L., and McCauley, J. R., 2006, Carboniferous-Permian boundary in Kansas, midcontinent, U.S.A.; in, Current Research in Earth Sciences: Kansas
Geological Survey, Bulletin 252, part 2, p. 1-13 (available online at www.kgs.ku.edu/Current/2006/sawin/index.html).

Skinner, J. W., 1931, New Permo-Pennsylvanian Fusulinidae from northern Oklahoma: Journal of Paleontology, v. 5, p. 16-22.

Skinner, J. W., and Wilde, G. L., 1965, Lower Permian (Wolfcampian) fusulinids from the Big Hatchet Mountains, southwestern New Mexico: Contributions from the Cushman Foundation for Foraminiferal Research, v. 16, part 3, p. 95-105.

Stevens, C. H., and Stone, P., 2007, The Pennsylvanian-Early Permian Bird Spring carbonate shelf, southeastern California; in, Fusulinid Biostratigraphy, Paleogeographic Evolution, and Tectonic Implications: Geological Society of America, Special Paper 429, 82 p.

Thompson, M. L., 1954, American Wolfcampian fusulinids: University of Kansas Paleontological Contributions, Protozoa, Article 5, p. 1-226.

Wahlman, G. P., 1998, Fusulinid biostratigraphy of the new Pennsylvanian-Permian boundary in the Southwest and midcontinent USA (abs.): Geological Society of America, Southcentral Section Annual Meeting, Abstracts with Program, v. 30, no. 3, p. 34.

Wahlman, G. P., and King, W. E., 2002, Late Pennsylvanian and earliest Permian stratigraphy and fusulinid biostratigraphy, Robledo Mountains and adjacent ranges, south-central New Mexico: New Mexico Bureau of Geology and Mineral Resources, Circular 208, 26 p.

Wahlman, G. P., and Kues, B. S., 2004, Late Pennsylvanian (Virgilian) fusulinaceans from the upper Atrasado and lower Red Tanks Formations, Carrizo Arroyo, Sierra Lucero, central New Mexico: New Mexico Museum of Natural History and Science, Bulletin No. 25, p. 127-136.

Wahlman, G. P., in prep., Pennsylvanian fusulinid biostratigraphy of the North American midcontinent; in, Carboniferous of the WorldMidcontinent North America, P. Heckel, ed.

West, R. R., compiler, 1994, Contributions to the geology of the rocks exposed by the "Flood of '93" at the Tuttle Creek Reservoir spillway near Manhattan, Kansas: Kansas Geological Survey, Openfile Report 94-36, $54 \mathrm{p}$.

Wilde, G. L., 2006, Pennsylvanian-Permian fusulinaceans of the Big Hatchet Mountains, New Mexico: New Mexico Museum of Natural History and Science, Bulletin 38, 331 p.

Wilde, G. L., 1990, Practical fusulinid zonation - the species concept; with Permian Basin emphasis: West Texas Geological Society, Bulletin 29 , p. 5-33.

Zeller, D. E., ed., 1968, The stratigraphic succession in Kansas: Kansas Geological Survey, Bulletin 189, 81 p. 

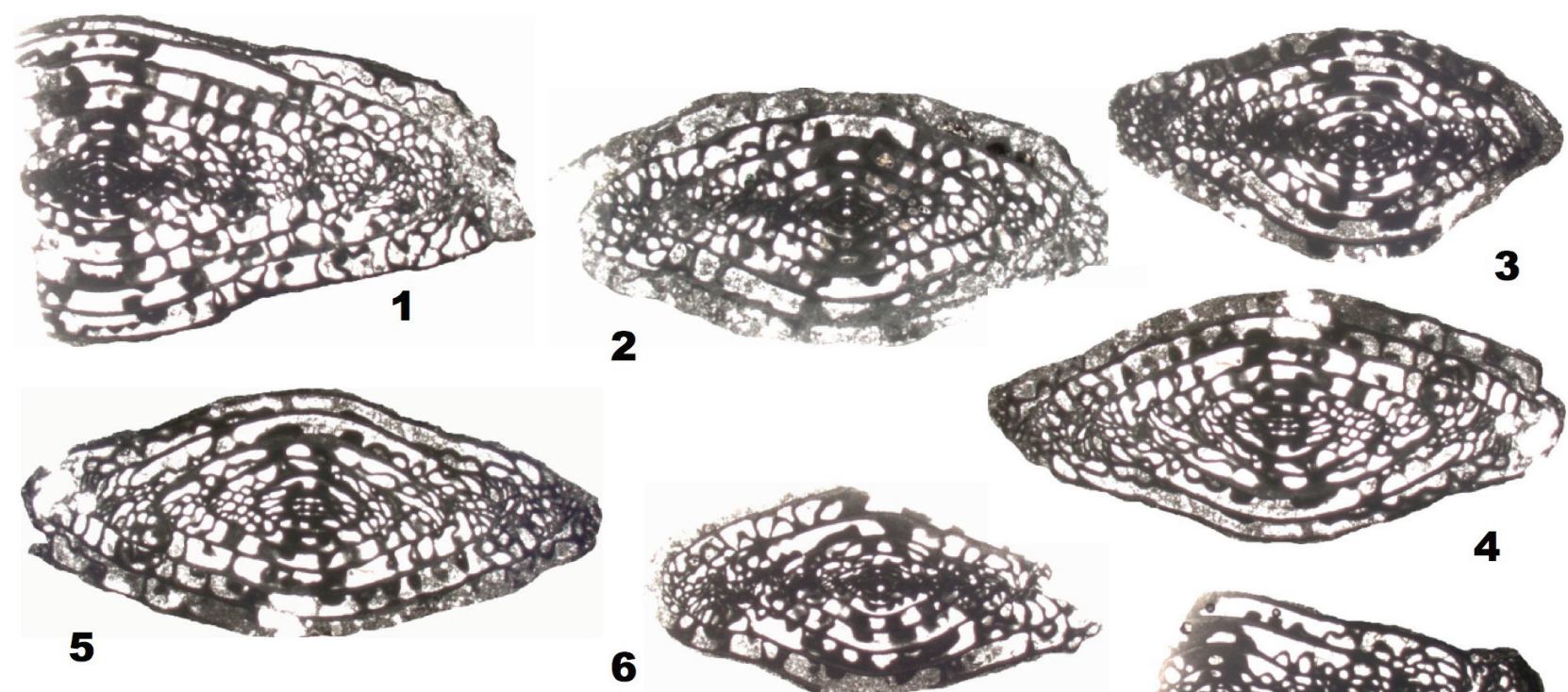

3

6
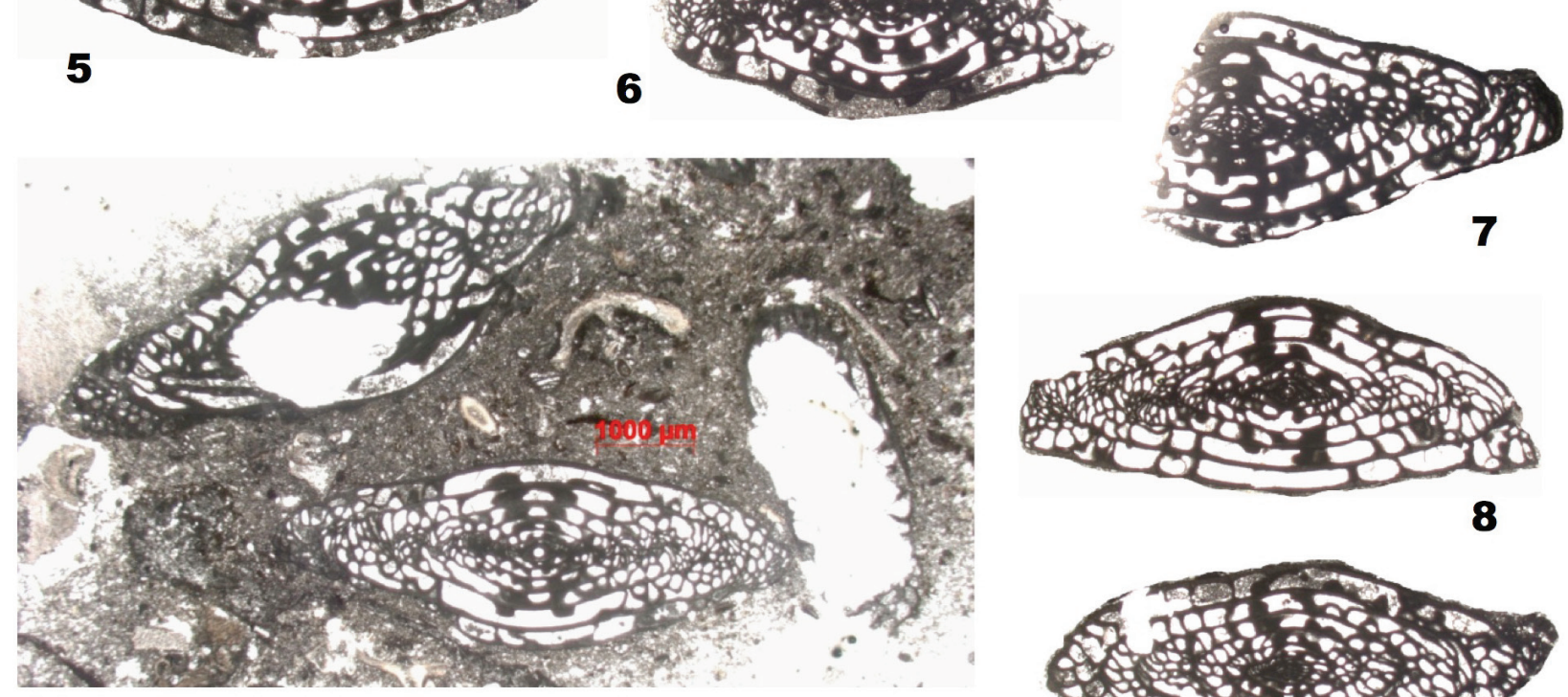

11

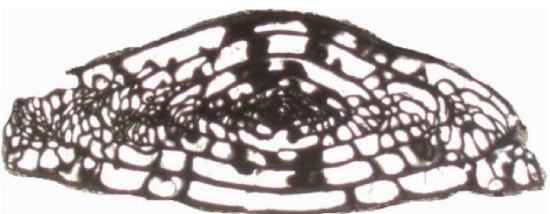

8
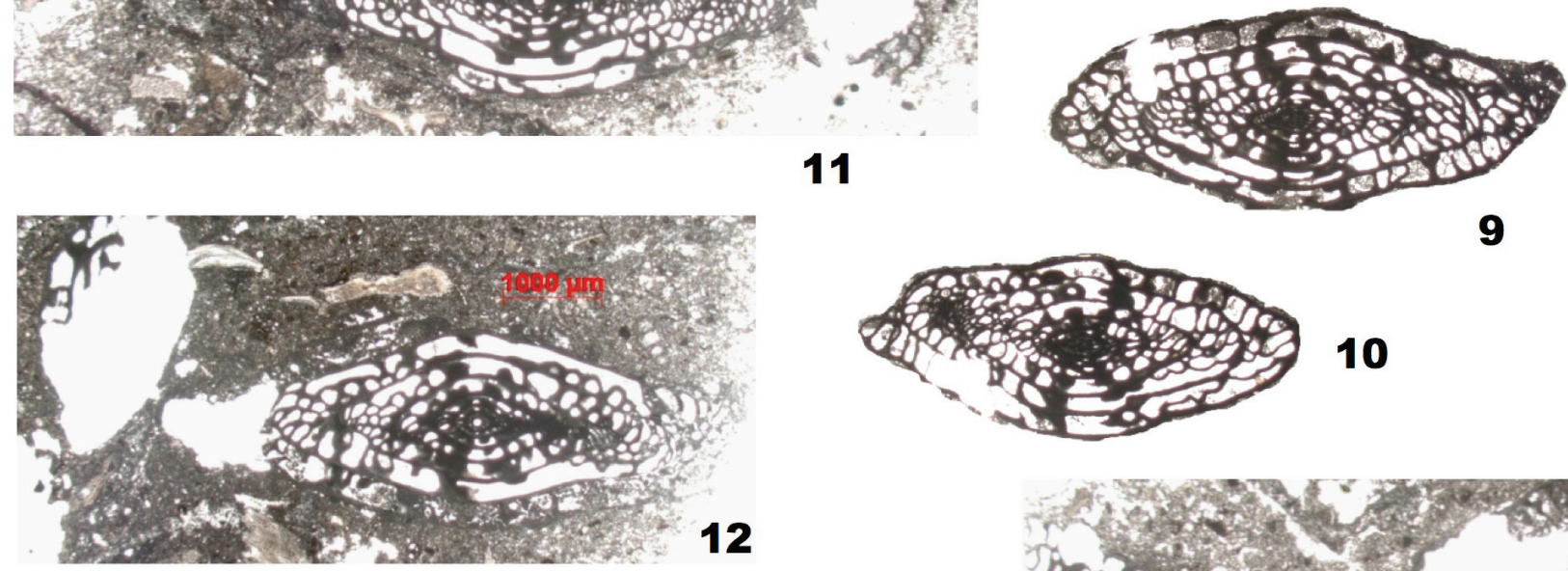

9
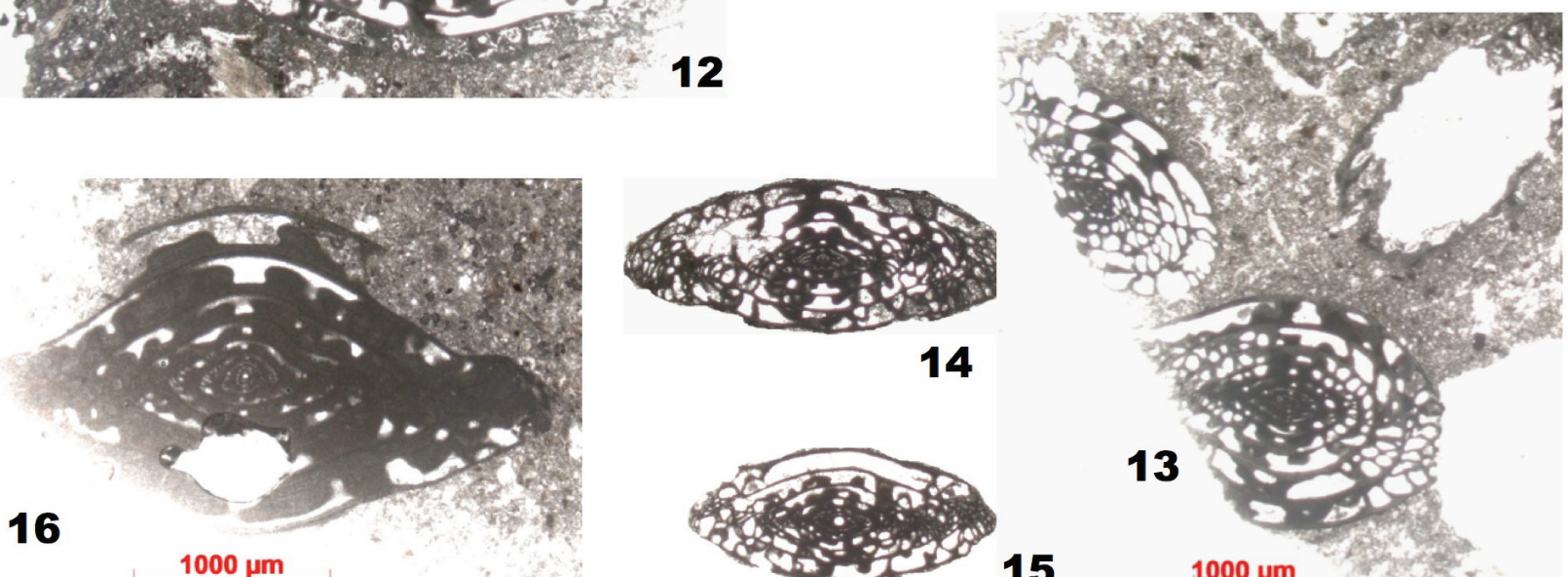

14
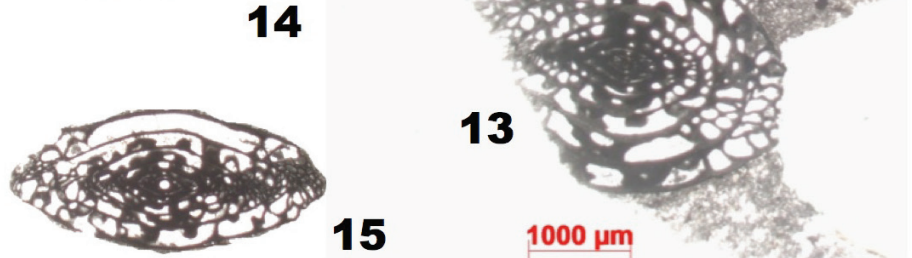

PLATE 1-Fusulinids from Locality 1. Figures 1-7-Leptotriticites glenensis Thompson, x10. Figures 8-15-Leptotriticites hughesensis Thompson, x10. Figure 16-Microspheric specimen of Leptotriticites sp., X25. Note that figs. 11, 12, and 13 show partially skelmoldic fusulinids (white areas) adjacent to preserved fusulinids. 

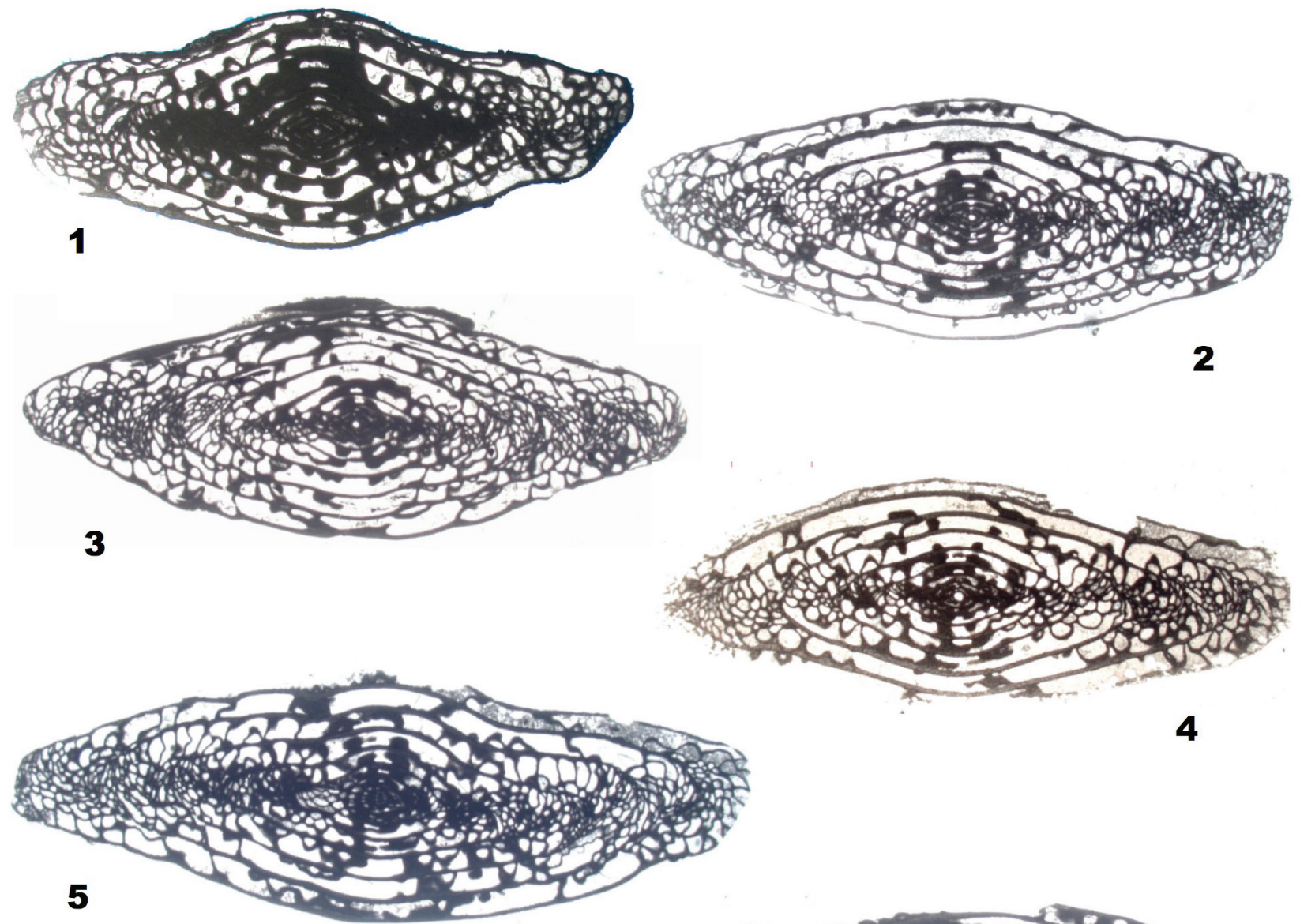

4

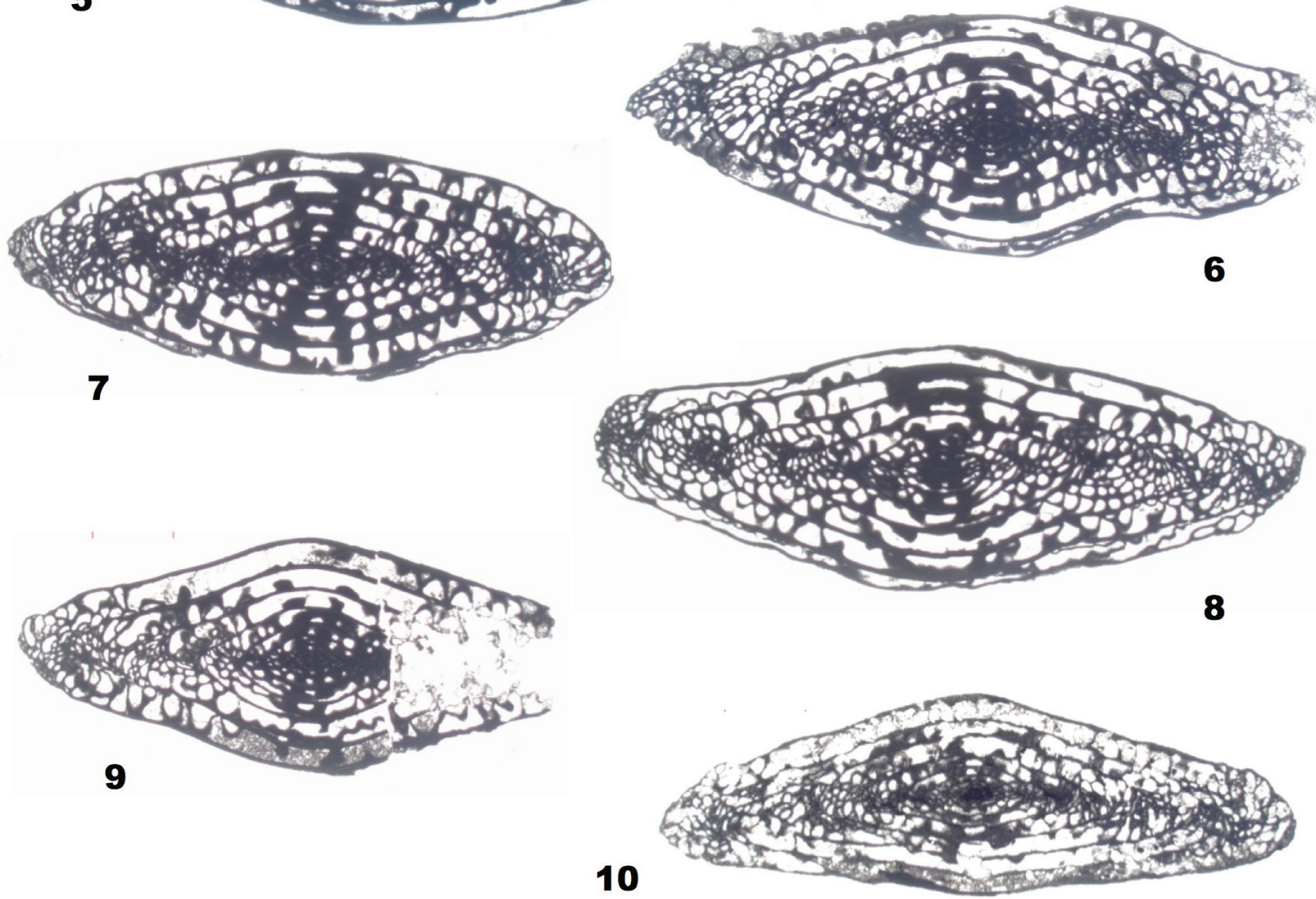

PLATE 2-Fusulinids from Locality 2. Figure 1-Leptotriticites glenensis Thompson, x10. Figures 2-4-Leptotriticites wetherensis Thompson, x10. Figures 5-9-Leptotriticites hughesensis Thompson, x10. Figure 10-Leptotriticites gracilitatus Skinner, x10. 